\title{
Antibody response after one and two doses of the BNT162b2 vaccine in nursing home residents: The CONsort-19 study
}

\author{
Jean Bousquet ${ }^{1}$, Hubert Blain ${ }^{2}$, Edouard Tuaillon ${ }^{2}$, Lucie Gamon ${ }^{2}$, Amandine Pisoni ${ }^{2}$, \\ Stephanie Miot ${ }^{2}$, Yves Rolland ${ }^{3}$, and Marie-Christine Picot ${ }^{2}$ \\ ${ }^{1}$ Université Versailles, St-Quentin-en-Yvelines \\ ${ }^{2} \mathrm{CHU}$ Montpellier \\ ${ }^{3} \mathrm{CHU}$
}

May 7, 2021

\begin{abstract}
Methods: Twenty-two French nursing homes were included. COVID-19 had been diagnosed with real-time reverse-transcriptase polymerase chain reaction (RT-PCR) for SARS-CoV-2. Blood S-protein IgG and nucleocapsid (N) IgG protein (N-protein IgG) were measured 21-24 days after the first jab (1,004 residents) and 6 weeks after the second (820 residents). Results: Among the 735 residents without prior COVID-19, $41.7 \%$ remained seronegative for S-protein IgG after the first jab vs $2.1 \%$ of the 270 residents with a previous positive RT-PCR $(\mathrm{p}<0.001)$. After the second jab, only $3 \%$ of the 586 residents without prior COVID-19 remained seronegative. However, $26.5 \%$ of them had low S-protein IgG levels (50-1050 UA/mL) vs $6.4 \%$ of the 222 residents with prior COVID-19. Residents with old infection (first wave), or seropositive for N-protein IgG at the time of vaccination, had the highest S-protein IgG levels. Residents with a prior COVID-19 infection had higher S-protein IgG levels after one dose than those without two jabs. Interpretation: A single vaccine jab is sufficient to reach immunity in residents with prior COVID-19. Most residents without prior COVID-19 are seropositive for S-protein IgG after the second jab, but around $30 \%$ have low levels of S-protein IgG. Whether residents with no or low post-vaccine immunity are at higher risk of symptomatic COVID-19 requires further analysis.
\end{abstract}

\section{Antibody response after one and two doses of the BNT162b2 vaccine in nursing home residents: The CONsort-19 study}

Hubert Blain, MD, PhD,${ }^{1}$ Edouard Tuaillon MD, PhD, ${ }^{2}$ Lucie Gamon, ${ }^{3}$ Amandine Pisoni PhD,${ }^{2}$ Stéphanie Miot MD, PhD,${ }^{1}$ Yves Rolland MD, PhD, ${ }^{4}$ Marie-Christine Picot MD, PhD ${ }^{3}$ Jean Bousquet MD, PhD ${ }^{5,6}$

1. Department of Internal Medicine and Geriatrics, MUSE University, Montpellier, France.

2. INSERM U 1058/EFS, University hospital, Montpellier, France

3. Clinical research and epidemiology unit, University hospital, Montpellier, France

4. Gérontopôle de Toulouse, INSERM 1027; Toulouse, France

5. Clinical research and epidemiology unit, University hospital, Montpellier, France

6. Department of Dermatology and Allergy, Universitätsmedizin, Berlin, Germany

7. University hospital, Montpellier, France

Running title: Antibody level after BNT162b2 vaccine

\section{Corresponding author:}

Prof. Hubert BLAIN, Department of Geriatrics, Montpellier University Hospital, Montpellier University, France. Full postal address: Centre Antonin Balmes, Pôle de Gérontologie du Centre Hospitalier Universi- 
taire de Montpellier , 39 avenue Charles Flahault, 34295 Montpellier Cedex 5, France. e-mail: h-blain@chumontpellier.fr; tel: +33 467339957 Fax: +33 467330948

\section{Summary of the article's main point:}

One BNT162b2 jab is sufficient for immunity in $98 \%$ of nursing home residents with prior COVID-19 and in $53.8 \%$ of residents without. After two jabs, levels of S-protein IgG are undetectable or low in $3.1 \%$ and $26.3 \%$ of residents with and without prior COVID-19, respectively.

\section{Abstract}

Background: There is insufficient information on the humoral immune response following COVID-19 vaccination in nursing home residents. A longitudinal study compared SARS-CoV-2 spike IgG (S-protein IgG) levels after one and two BNT162b2/Pfizer jabs in residents with and without prior COVID-19.

Methods: Twenty-two French nursing homes were included. COVID-19 had been diagnosed with realtime reverse-transcriptase polymerase chain reaction (RT-PCR) for SARS-CoV-2. Blood S-protein IgG and nucleocapsid (N) IgG protein (N-protein IgG) were measured 21-24 days after the first jab (1,004 residents) and 6 weeks after the second ( 820 residents).

Results: Among the 735 residents without prior COVID-19, 41.7\% remained seronegative for S-protein IgG after the first jab vs $2.1 \%$ of the 270 residents with a previous positive RT-PCR $(\mathrm{p}<0.001)$. After the second jab, only $3 \%$ of the 586 residents without prior COVID-19 remained seronegative. However, $26.5 \%$ of them had low S-protein IgG levels (50-1050 UA/mL) vs $6.4 \%$ of the 222 residents with prior COVID-19. Residents with old infection (first wave), or seropositive for N-protein IgG at the time of vaccination, had the highest S-protein IgG levels. Residents with a prior COVID-19 infection had higher S-protein IgG levels after one dose than those without two jabs.

Interpretation: A single vaccine jab is sufficient to reach immunity in residents with prior COVID-19. Most residents without prior COVID-19 are seropositive for S-protein IgG after the second jab, but around 30\% have low levels of S-protein IgG. Whether residents with no or low post-vaccine immunity are at higher risk of symptomatic COVID-19 requires further analysis.

Key words: COVID-19, BNT162b2/Pfizer vaccine, nursing home, rRT-PCR, antibodies against SARS$\mathrm{CoV}-2$

\section{Background}

Nursing Home (NH) residents are at high risk of serious illness and death from COVID-19 due to Severe Acute Respiratory Syndrome Coronavirus-2 (SARS-CoV-2) ${ }^{1}$. In NHs facing a COVID-19 outbreak, infection prevention and control (IPC) measures based on results of repeated testing by real-time reverse-transcriptase polymerase chain reaction for SARS-CoV-2 (RT-PCR) in all residents can limit coronavirus transmission ${ }_{2,3}$. Residents with a prior COVID-19 may be protected against reinfection during outbreaks in $\mathrm{NHs}^{4}$.

Vaccination against SARS-CoV-2 is safe and effective in preventing COVID-19 in adults ${ }^{5}$, and immunocompetent SARS-CoV-2 seropositive adults might only require one dose of the Pfizer-BioNTech or the Moderna mRNA vaccines to reach immunity ${ }^{6,7}$.

Age or immune dysregulation may impact immune response to COVID-19 and vaccination. The level of $\mathrm{N}$-protein IgG produced after SARS-CoV-2 infection, associated with a substantially reduced risk of SARS$\mathrm{CoV}-2$ reinfection ${ }^{8}$, declines over time ${ }^{9}$. In the Danish Microbiology Database, protection against repeat infection was found to be reduced in participants over 65 years $^{10}$. Age seems also to reduce serological response after vaccination of kidney ${ }^{11}$ or liver transplant recipients ${ }^{12}$, and of patients with chronic lymphocytic leukemia, ${ }^{13}$ cancer ${ }^{14}$ or hemodialysis. ${ }^{15}$

Few data exist on post-vaccine immunity in $\mathrm{NH}$ residents, and the size of the study is usually low. After one jab, binding antibodies against S-protein were approximately 4-fold lower in residents compared to healthcare professionals. ${ }^{16,17}$ Although the increment of antibody levels after the second immunisation may be higher 
in older participants, the absolute mean titer of this group seems to remain lower in NH residents aged over 80 years than in those under $60 .^{18}$

A pilot study showed that NH residents having had COVID-19 in the past 9-12 months had much higher levels of antibodies against the SARS-CoV-2 S-protein (S-protein IgG) after a single BNT162b2 jab than residents not having had COVID-19 ${ }^{16}$.

It remains therefore necessary $i$ ) to confirm in a large sample of residents whether the S-protein IgG response after a single BNT162b2 jab may be influenced by prior COVID-19 infection, ii) to determine in former COVID-19 residents whether the S-protein IgG response after a single BNT162b2 jab may be influenced by the time elapsed since the COVID-19 infection and by the persistence of a natural immunity against Nprotein and (iii) to assess the S-protein IgG response after a second vaccination in residents with or without prior COVID-19.

We first compared S- and N-protein IgG levels 3 weeks after a single BNT162b2 jab in a large group of residents with vs without prior COVID-19 confirmed by RT-PCR (RT-PCR-positive residents). Two periods were considered - the past 9 to 12 months (older infections) and the past 3 to 7 months (newer infections) corresponding to the first and second waves of the epidemic in our region (March-June 2020 and SeptemberDecember 2020). Secondly, we assessed the S-protein IgG response in these residents 6 weeks after a second vaccination.

\section{Methods}

\section{Design}

A longitudinal study was carried out in NHs having faced a COVID-19 outbreak in 2020. Firstly, we compared N- and S-protein IgG levels three weeks after a single BNT162b2 jab in residents without prior COVID19 (with repeated negative RT-PCR and negative N-protein IgG measured 3 weeks after the jab) and in residents with prior COVID-19 (confirmed either by a positive RT-PCR or by detectable N-protein IgG). Two periods were considered - the past 9 to 12 months (older infections) and the past 3 to 7 months (newer infections) - corresponding to the first and second waves of the epidemic in our region.

Secondly, S-protein levels were compared six weeks after a second BNT162b2 jab in residents with or without prior COVID-19.

\section{Settings}

We included $22 \mathrm{NHs}$ of the Montpellier area (France), each with at least five residents with a previous diagnosis of COVID-19 confirmed by RT-PCR on a nasopharyngeal swab test between March and December 2020 (PCR-positive residents). This study follows previous studies conducted in the same NHs with a COVID19 outbreak between March and June 202016,19,20.

\section{Participants}

As previously reported ${ }^{16,19,20}$, as soon as a resident developed COVID-19 in a NH, all residents and staff members were repeatedly tested using RT-PCR on nasopharyngeal swabs until no new cases were diagnosed. This was the procedure recommended by the Health Agency of our region, in accordance with the European Geriatric Medicine Society guidance ${ }^{3}$.

All residents who had not had COVID-19 in the last 3 months, and who signed an informed consent, were offered a first jab of the BNT162b2 vaccine between January and March 2021. According to the national recommendations in NHs, a second jab, irrespective of prior COVID-19 history, was offered three weeks later. Residents and their family, relatives or legal representative were informed of the possibility to measure the antibody response after the first and second jabs and of the fact that the residents' anonymised clinical and biological data would be used for research purposes. The study was approved by the Montpellier University Hospital institutional review board (IRB-MTP_2020_06_202000534 and IRB-MTP_2021_04_202000534).

\section{Outcomes}


S-protein IgG against the SARS-CoV-2 Receptor-Binding Domain (RBD) of the S1 subunit was detected using the SARS-CoV-2 IgG II Quant assay (Abbott Diagnostics). Results were expressed as arbitrary units per $\mathrm{mL}(\mathrm{AU} / \mathrm{mL}$; positive threshold: $50 \mathrm{AU} / \mathrm{mL}$; upper limit: 40,000 $\mathrm{AU} / \mathrm{mL}$; a level [?] 1,050 AU/mL was considered as a significant response ${ }^{21}$ and a level [?] $4160 \mathrm{AU} / \mathrm{mL}$ as a level indicating a high neutralising effect according to the manufacturer). N-protein IgG were detected using the SARS-CoV-2 IgG assay (Abbott Diagnostics). Results were expressed as signal to cutoff ratio (S/CO; Abbott Alinity; positive threshold: 0.8 $\mathrm{S} / \mathrm{CO})^{22}$.

\section{Sample size}

The sample size was not calculated since we aimed to study all possible NH residents.

\section{Statistical analysis}

Qualitative variables were described with frequency and proportions for each category. The description of quantitative variables was performed using mean and standard deviation and/or median, minimum and maximum values. N-protein and S-protein IgG levels were compared in residents $i$ ) with and without prior COVID-19, ii ) with prior COVID-19 during the first or second wave of the epidemic, andiii ) between those who remained or did not remain seropositive for N-protein IgG. Wilcoxon-Mann-Whitney 2-sided tests were used, qualitative variables were compared using a chi-2 test, and the statistical significance threshold was set at 5\%. Analyses were performed using the SAS Enterprise Guide, v7.3 (SAS Institute Inc.).

\section{Results}

\section{Demographic characteristics of the residents}

Among the 1,243 eligible residents, 1,004 were analysed to assess the antibody response after the first jab. Seven hundred and thirty-five residents had always tested negative for SARS-CoV-2 RNA by RT-PCR, 94 had tested positive 9 to 12 months before the vaccine and 176 had tested positive 3 to 7 months before. Among those 1,004 residents, 808 accepted the second jab and agreed to participate in the study (Figure 1).

\section{N-Protein IgG levels 6 weeks after the first BNT162b2 jab}

N-protein IgG were detectable ([?] 0.8 signal to cutoff ratio) in $42(5.7 \%)$ of the 735 negative RT-PCR residents. These residents were then considered as immunised against SARS-CoV-2. Residents with an older infection were less frequently seropositive for N-protein IgG than residents with a newer infection (61.1\% vs $83.7 \%, \mathrm{p}<.001$ ) (Table 1). The N-protein IgG median level was lower in residents with an older infection than in those with a newer infection $(\mathrm{p}<0.001)$.

\section{S-protein IgG levels 6 weeks after the first BNT162b2 jab}

S-protein IgG was undetectable $(<50 \mathrm{AU} / \mathrm{mL})$ in $41.7 \%$ of the RT-PCR-negative residents who had tested negative for N-protein IgG, in $11.9 \%$ of the residents with a negative RT-PCR but who were positive for $\mathrm{N}$-protein IgG, in $2.1 \%$ of residents with an older infection, and in $4.6 \%$ with a newer infection (Table 1).

A low S-protein IgG level ([?] 1,050 UA/ ml) was more often observed in residents without prior COVID-19 (negative for both RT-PCR and N-protein IgG tests) than in residents with a previous positive RT-PCR (91.3\% vs $11.5 \%, \mathrm{p}<0.001)$. RT-PCR-positive residents with an older infection more often had a high S-protein IgG level than those with a newer infection $(88.3 \%$ vs $84.0 \%, \mathrm{p}<0.001)$, and RT-PCR-negative residents tested positive for N-protein IgG ( $88.3 \%$ vs $73.8 \%, \mathrm{p}<0.001)$.

The predictive value of a high S-protein IgG level ([?] 4,160 UA/ ml) by a prior RT-PCR in the last 3 to 12 months was high (positive predictive value of $85.5 \%$ [83.3\%-87.7\%] and negative predictive value of $94.0 \%$ [92.5\%-95.5\%]).

\section{Link between S- and N-Protein IgG levels after the first BNT162b2 dose}

Among the RT-PCR-positive residents, the median levels of S-protein IgG after vaccine were ranked in the following order: $i$ ) residents with a newer infection and no detectable N-protein IgG (median value of 
$230 \mathrm{AU} / \mathrm{mL}$ ), ii ) residents with a newer infection and detectable N-protein IgG (median value of 20,685 $\mathrm{AU} / \mathrm{mL}$ ), iii ) residents with an older infection and no detectable N-protein IgG (median value of 27,313 $\mathrm{AU} / \mathrm{mL}$ ), and $i v$ ) residents with an older infection and detectable N-protein IgG (median value of 40,000 $\mathrm{AU} / \mathrm{mL}$ )(Table 2, Figure 2).

The predictive value of a high S-protein IgG level ([?] 4,160 UA/ ml) by N-protein IgG ([?] 0.8 signal to cutoff ratio) was high (positive predictive value of $92.5 \%$ [90.8\%-94.2\%] and negative predictive value of 93.0\% [91.4\%-94.6\%]).

\section{S-protein IgG levels 6 weeks after the second BNT162b2 jab}

Six weeks after the second BNT162b2 jab, only around 3\% of the 554 residents without prior COVID-19 had undetectable S-protein IgG levels $(<50 \mathrm{AU} / \mathrm{mL}$ ) vs none of the residents with a prior positive PCR (Table 3). The prevalence of residents with low S-protein IgG levels ([?] 1,050 AU/mL) was significantly lower in residents without prior COVID-19 than in those with a positive PCR in the 3 to 12 last months (28.3\% vs $2.7 \%, \mathrm{p}<0.001$ ) (Figure 3). The median value of S-protein IgG in residents without prior COVID-19 after two vaccine doses was 10-fold lower than that in residents with prior COVID-19 after one dose $(2,384$ $\mathrm{AU} / \mathrm{mL}$ vs $23,259 \mathrm{AU} / \mathrm{mL}$ )

\section{Discussion}

Recent studies conducted in small samples of immunocompetent adults showed higher levels of S-protein IgG after a single jab in individuals with prior COVID-19 than in those without prior COVID-19. ${ }^{5,23}$ Our pilot study with 136 residents was the only one to include NH residents. ${ }^{16}$ The current study is innovative because it includes a large sample of $\mathrm{NH}$ residents and evaluates the effect on antibody response of (i) the time elapsed since COVID-19 infection and vaccination, and (ii) the persistence of a natural immunity against SARS-CoV-2 N-protein at the time of the first vaccination. The large sample allows the assessment of the percentage of residents with undetectable S-protein IgG $(<50 \mathrm{AU} / \mathrm{mL})$ or with low levels of S-protein ([?]1050 AU/mL) after two vaccine doses among those with or without prior COVID-19. It also enables the comparison of antibody response after one jab in residents without COVID-19 and after two doses in residents with prior COVID-19.

The present study shows that 3 weeks after the first vaccine dose: $i$ ) $41.7 \%$ of residents without prior COVID19 have undetectable S-protein IgG and $91.3 \%$ have low levels of S-protein IgG, ii ) only $3.8 \%$ of residents without prior COVID-19 have undetectable S-protein IgG and 11.5\% have low levels of S-protein IgG, iii ) among residents with prior COVID-19, those seropositive for N-protein at the time of the vaccine and those with an older infection (in the last 9 to 12 months) have the highest S-protein IgG levels, iv ) the second jab significantly boosts the antibody response of residents without prior COVID-19 (since 6 weeks after the second dose, only $3.1 \%$ remain seronegative for S-protein IgG). However, $v$ ) $29.4 \%$ of residents without prior COVID-19 have low S-protein IgG levels, vi ) in residents with prior COVID-19, the second dose leads to a reduced percentage of residents with low S-protein IgG levels (from $11.5 \%$ after the first dose to $2.7 \%$ after the second dose). The median value of S-protein IgG levels after one jab in residents with prior COVID-19 exceeds that of two doses in residents without prior COVID-19.

Findings of the present study in light of current publications on residents with prior COVID-19

Three weeks after a single dose of BNT162b2 vaccine, residents with an older infection were less often seropositive for N-protein IgG than those with a newer infection $(61.1 \%$ vs $85.7 \%)$. This result accords with the time-related decline of natural SARS-CoV-2 antibodies observed not only in the general population with prior COVID-19 ${ }^{24}$ but also in NHs: a study showed that $91 \%$ of residents were still seropositive for N-protein 6 months after COVID-19, but with a decreasing antibody titer over time ${ }^{25}$. The rapid decay of $\mathrm{N}$-protein IgG in the 90 days after mild COVID-19 infection has suggested a short-lasting humoral immunity against SARS-CoV-2 ${ }^{26}$. The present study is quite reassuring as it indicates a natural immunity in $61 \%$ of $\mathrm{NH}$ residents 9 to 12 months after infection, which is in line with the results shown after other acute viral infections ${ }^{27,28}$. 
This study shows a link between N-protein IgG and S-protein IgG levels after the first jab. RT-PCR-positive residents who were seropositive for N-protein IgG more often exhibited a high S-protein IgG level after vaccination (over $96 \%$ of them) than seronegative residents with a positive RT-PCR from an older $(80 \%)$ or newer $(28.6 \%)$ infection. This result is in line with influenza for which pre-existing immunity in older individuals, contrary to immune-senescence or poor functional status, is a strong correlate of post-vaccination immunity ${ }^{29,30}$.

It is reassuring to note that $80 \%$ of the RT-PCR-positive residents with an older infection but who do not have a persistent humoral immunity exhibit a high S-protein IgG level after the vaccine. This result suggests a long-term persistence of previously-generated memory B cells that can induce a rapid clonal expansion and terminal differentiation to produce high affinity anti-S-protein IgG after the vaccine ${ }^{31}$, as observed for common viruses $^{32}$. In line with this hypothesis, a robust boosting after the first mRNA jab was found to strongly correlate with levels of pre-existing memory B cells in recovered individuals, identifying a key role for memory B cells in recall responses to SARS-CoV-2 antigens ${ }^{33}$. Taken together, these results suggest that both natural humoral immunity (that appears to decrease over time) and cellular immunity (that seems to be maintained over time) may modulate the high level of SARS-CoV-2 S-protein IgG following a single BNT162b2 jab in nursing home residents having recovered from COVID-19. This highlights the utility of defining cellular responses in addition to serologies to predict the immune response to vaccine in this population. This result may be important since the role of pre-existing immunity was underscored during the $2009 \mathrm{~A}\left(\mathrm{H}_{1} \mathrm{~N}_{1}\right)$ pandemic, when older adults were less severely affected than younger individuals ${ }^{34}$.

The present study shows that NH residents with prior COVID-19 achieve much higher S-protein IgG levels after one single jab than in younger COVID-19 convalescents ${ }^{35}$. It remains to be determined whether vaccinated residents with prior COVID-19 (with at least one jab) will be better protected against reinfection during outbreaks in NHs than unvaccinated residents with prior COVID-19 ${ }^{4}$.

The persistence of N-protein IgG in $85.7 \%$ of residents with a newer infection (in the past 3 to 7 months) and the increase in S-protein level observed with increasing time between COVID-19 and vaccination both support the hypothesis that, in most residents, the vaccine should be administered at least 3 months after COVID-19 infection, even if reinfection is possible within those 3 months ${ }^{36}$.

\section{Strengths and limitations of the study}

This study has several strengths. Our sample is probably representative of the population of NH residents in France since it was conducted on a large sample of residents who were tested across $22 \mathrm{NHs}$ facing a COVID-19 outbreak. Ascertainment of positive and negative RT-PCR results is probably almost complete since all studied NHs followed the same regional Health Agency guidance published in March $2020^{2,3}$. We used an automated quantitative assay to measure the RBD IgG level that correlates well with virus neutralisation ${ }^{37,38}$. N-protein IgG measurement in all individuals allowed us to differentiate residents with SARS-CoV-2 immunisation while having repeated negative RT-PCR tests.

The main limitation of the study is the lack of clinical outcome. It remains indeed to demonstrate that a single BNT162b2 jab in residents having recovered from COVID-19 has the same efficacy in preventing reinfection as two doses. If the N-protein IgG level is associated with a substantially reduced risk of SARS$\mathrm{CoV}-2$ reinfection ${ }^{8}$, there is no available publication demonstrating a link between the S-protein IgG level obtained after the vaccine and the risk of incident SARS-CoV-2 infection and of symptomatic or severe COVID-19. It remains to be determined whether the thresholds we have chosen to define a low level ([?] $1050 \mathrm{AU} / \mathrm{mL}$ ) or a high S-protein IgG after the vaccine ([?] 4,160 AU/mL) are effectively associated with an increased or decreased risk of developing SARS-CoV-2 infection. ${ }^{7}$ This is particularly important since serum neutralising activities against SARS-CoV-2 six months after COVID-19 hospitalisation remain significant for ancestral strains and for the D614G and B.1.16 variants but are weaker for the B.1.351 variant ${ }^{39}$. It is therefore plausible that the post-vaccine S-protein $\operatorname{IgG}$ level necessary to obtain protection against new variants may be higher than previously defined ${ }^{40}$.

\section{Generalisability}


Although this study has been carried out in one European region, its size allows generalisability in residents infected by the natural strain of the virus. New studies are needed to study the post-vaccine antibody response in residents infected by different variants.

\section{Conclusions}

Recent studies show that even if the vaccine is very effective in reducing severe forms of COVID-19 in nursing home residents, the vaccination, even complete, may not totally prevent the risk of SARS-CoV-2 outbreaks in nursing homes (Blain et al., submitted). ${ }^{41}$

This present study supports the hypothesis that $i$ ) most of the residents having recovered from COVID-19 (with a diagnosis using RT-PCR or N-protein IgG) may only require one single vaccine dose to achieve peak antibody and memory B cell responses. ii ) However, the second dose reduces the prevalence of residents with low S-protein IgG levels ([?]1050 AU/mL)(from $11.5 \%$ to $2.7 \%$ ). iii ) For individuals whose infection history is unknown, measuring S-protein IgG antibody levels just before the second jab could be useful in determining whether a second dose is required. $i v$ ) Most of the individuals without prior COVID-19 have a low level of S-protein IgG 3 weeks after the first jab, further confirming the benefit to administer the second dose without delay to boost the antibody response. After two doses, around $30 \%$ of residents without prior COVID-19 have a low level of S-protein IgG. Whether these residents with low antibody response after the complete vaccine regimen are at higher risk of symptomatic COVID-19 and whether they may benefit from a third vaccine dose remains to be further investigated.

Additional studies are required to demonstrate whether the measure of S-protein IgG after the vaccination should help to personalise the vaccine schedules and reduce secondary effects related to possible reactogenicity 42. Further studies are necessary also to determine whether the present results obtained in residents infected by the natural strain of the virus may be replicated in residents infected by the new variants ${ }^{43,44}$.

\section{Funding:}

This research did not receive any funding from agencies in the public, commercial, or not-for-profit sectors.

\section{Acknowledgements:}

The authors would like to thank Anna Bedbrook, Fabienne Portejoie, (MACVIA France), Eva Pons (Master Metiers de l'Enseignement, de l'Education et de la Formation; education nationale francaise, Lyon), for editorial assistance, Joy Martin, Isabelle Bussereau, and Marie-Suzanne Leglise, Secours Infirmiers (Department of Geriatrics, Montpellier University Hospital), Veronique Vera and Florence Biblocque (admission office, Montpellier University Hospital) for material support, as well as the residents and staff members of the nursing homes involved in the study. None of these contributors received any compensation for their help in carrying out the study.

\section{Conflicts of Interest:}

The authors declare no conflicts of interest/competing interests

\section{Abbreviations}

N-protein IgG: nucleocapsid (N) IgG protein

NH: Nursing home

RT-PCR: real-time reverse-transcriptase polymerase chain reaction for SARS-CoV-2

S-protein IgG: SARS-CoV-2 spike IgG

SARS-CoV-2: Severe Acute Respiratory Syndrome Coronavirus-2

\section{References}


1. McMichael TM, Currie DW, Clark S, et al. Epidemiology of Covid-19 in a Long-Term Care Facility in King County, Washington. N Engl J Med. 2020.

2. Blain H, Rolland Y, Tuaillon E, et al. Efficacy of a Test-Retest Strategy in Residents and Health Care Personnel of a Nursing Home Facing a COVID-19 Outbreak. J Am Med Dir Assoc. 2020;21(7):933-936.

3. Blain H, Rolland Y, Schols J, et al. August 2020 Interim EuGMS guidance to prepare European LongTerm Care Facilities for COVID-19.Eur Geriatr Med. 2020;11(6):899-913.

4. Jeffery-Smith A, Iyanger N, Williams SV, et al. Antibodies to SARS-CoV-2 protect against re-infection during outbreaks in care homes, September and October 2020. Euro Surveill. 2021;26(5).

5. Polack FP, Thomas SJ, Kitchin N, et al. Safety and Efficacy of the BNT162b2 mRNA Covid-19 Vaccine. $N$ Engl J Med.2020;383(27):2603-2615.

6. Saadat S, Rikhtegaran Tehrani Z, Logue J, et al. Binding and Neutralization Antibody Titers After a Single Vaccine Dose in Health Care Workers Previously Infected With SARS-CoV-2. JAMA.2021;325(14):14671469.

7. Ebinger JE, Fert-Bober J, Printsev I, et al. Antibody responses to the BNT162b2 mRNA vaccine in individuals previously infected with SARS-CoV-2. Nat Med. 2021.

8. Lumley SF, O'Donnell D, Stoesser NE, et al. Antibody Status and Incidence of SARS-CoV-2 Infection in Health Care Workers. N Engl J Med. 2021;384(6):533-540.

9. Padoan A, Dall'Olmo L, Rocca FD, et al. Antibody response to first and second dose of BNT162b2 in a cohort of characterized healthcare workers. Clin Chim Acta. 2021;519:60-63.

10. Hansen CH, Michlmayr D, Gubbels SM, Molbak K, Ethelberg S. Assessment of protection against reinfection with SARS-CoV-2 among 4 million PCR-tested individuals in Denmark in 2020: a populationlevel observational study. Lancet. 2021;397(10280):1204-1212.

11. Rabinowich L, Grupper A, Baruch R, et al. Low immunogenicity to SARS-CoV-2 vaccination among liver transplant recipients. J Hepatol. 2021.

12. Korth J, Jahn M, Dorsch O, et al. Impaired Humoral Response in Renal Transplant Recipients to SARS-CoV-2 Vaccination with BNT162b2 (Pfizer-BioNTech). Viruses. 2021;13(5).

13. Herishanu Y, Avivi I, Aharon A, et al. Efficacy of the BNT162b2 mRNA COVID-19 Vaccine in Patients with Chronic Lymphocytic Leukemia.Blood. 2021.

14. Jerome B, Emmanuel C, Zoubir A, et al. Impaired immunogenicity of BNT162b2 anti SARS-CoV-2 vaccine in patients treated for solid tumors.Ann Oncol. 2021.

15. Jahn M, Korth J, Dorsch O, et al. Humoral Response to SARS-CoV-2-Vaccination with BNT162b2 (Pfizer-BioNTech) in Patients on Hemodialysis. Vaccines (Basel). 2021;9(4).

16. Blain H, Tuaillon E, Gamon L, et al. Spike Antibody Levels of Nursing Home Residents With or Without Prior COVID-19 3 Weeks After a Single BNT162b2 Vaccine Dose. JAMA. 2021.

17. Brockman MA, Mwimanzi F, Sang Y, et al. Weak humoral immune reactivity among residents of long-term care facilities following one dose of the BNT162b2 mRNA COVID-19 vaccine. medRxiv. 2021.

18. Muller L, Andree M, Moskorz W, et al. Age-dependent immune response to the Biontech/Pfizer BNT162b2 COVID-19 vaccination. Clin Infect Dis. 2021.

19. Blain H, Rolland Y, Benetos A, et al. Atypical clinical presentation of COVID-19 infection in residents of a long-term care facility.Eur Geriatr Med. 2020;11(6):1085-1088.

20. Blain H, Gamon L, Tuaillon E, et al. Atypical symptoms, SARS-CoV-2 test results, and immunization rates in 456 residents from eight nursing homes facing a COVID-19 outbreak. Age Ageing. 2021. 
21. Van Praet JT, Vandecasteele S, De Roo A, De Vriese AS, Reynders M. Humoral and cellular immunogenicity of the BNT162b2 mRNA Covid-19 Vaccine in nursing home residents. Clin Infect Dis. 2021.

22. Tuaillon E, Bollore K, Pisoni A, et al. Detection of SARS-CoV-2 antibodies using commercial assays and seroconversion patterns in hospitalized patients. J Infect. 2020;81(2):e39-e45.

23. Gobbi F, Buonfrate D, Moro L, et al. Antibody Response to the BNT162b2 mRNA COVID-19 Vaccine in Subjects with Prior SARS-CoV-2 Infection. Viruses. 2021;13(3).

24. Bolotin S, Tran V, Osman S, et al. SARS-CoV-2 seroprevalence survey estimates are affected by anti-nucleocapsid antibody decline. J Infect Dis. 2021.

25. Ruopp MD, Strymish J, Dryjowicz-Burek J, Creedon K, Gupta K. Durability of SARS-CoV-2 IgG Antibody Among Residents in a Long-Term Care Community. J Am Med Dir Assoc. 2021;22(3):510-511.

26. Ibarrondo FJ, Fulcher JA, Goodman-Meza D, et al. Rapid Decay of Anti-SARS-CoV-2 Antibodies in Persons with Mild Covid-19. N Engl J Med. 2020;383(11):1085-1087.

27. Wajnberg A, Amanat F, Firpo A, et al. Robust neutralizing antibodies to SARS-CoV-2 infection persist for months. Science.2020;370(6521):1227-1230.

28. Seow J, Graham C, Merrick B, et al. Longitudinal observation and decline of neutralizing antibody responses in the three months following SARS-CoV-2 infection in humans. Nat Microbiol.2020;5(12):15981607.

29. Reber AJ, Kim JH, Biber R, et al. Preexisting Immunity, More Than Aging, Influences Influenza Vaccine Responses. Open Forum Infect Dis. 2015;2(2):ofv052.

30. Van Epps P, Tumpey T, Pearce MB, et al. Preexisting Immunity, Not Frailty Phenotype, Predicts Influenza Postvaccination Titers among Older Veterans. Clin Vaccine Immunol. 2017;24(3).

31. Gaebler C, Wang Z, Lorenzi JCC, et al. Evolution of antibody immunity to SARS-CoV-2. Nature. 2021;591(7851):639-644.

32. Amanna IJ, Carlson NE, Slifka MK. Duration of humoral immunity to common viral and vaccine antigens. N Engl J Med.2007;357(19):1903-1915.

33. Goel RR, Apostolidis SA, Painter MM, et al. Distinct antibody and memory B cell responses in SARSCoV-2 naive and recovered individuals following mRNA vaccination. Sci Immunol. 2021;6(58).

34. Gaglani M, Spencer S, Ball S, et al. Antibody response to influenza A(H1N1)pdm09 among healthcare personnel receiving trivalent inactivated vaccine: effect of prior monovalent inactivated vaccine. $J$ Infect Dis. 2014;209(11):1705-1714.

35. Azzi L, Focosi D, Dentali F, Baj A, Maggi F. Anti-SARS-CoV-2 RBD IgG responses in convalescent versus naive BNT162b2 vaccine recipients. Vaccine. 2021;39(18):2489-2490.

36. Tillett RL, Sevinsky JR, Hartley PD, et al. Genomic evidence for reinfection with SARS-CoV-2: a case study. Lancet Infect Dis.2021;21(1):52-58.

37. Salazar E, Kuchipudi SV, Christensen PA, et al. Convalescent plasma anti-SARS-CoV-2 spike protein ectodomain and receptor-binding domain IgG correlate with virus neutralization. $J$ Clin Invest.2020;130(12):6728-6738.

38. Wang Z, Schmidt F, Weisblum Y, et al. mRNA vaccine-elicited antibodies to SARS-CoV-2 and circulating variants. Nature.2021;592(7855):616-622.

39. Betton M, Livrozet M, Planas D, et al. Sera neutralizing activities against SARS-CoV-2 and multiple variants six month after hospitalization for COVID-19. Clin Infect Dis. 2021. 
40. Hoffmann M, Arora P, Gross R, et al. SARS-CoV-2 variants B.1.351 and P.1 escape from neutralizing antibodies. Cell. 2021.

41. Cavanaugh AM, Fortier S, Lewis P, et al. COVID-19 Outbreak Associated with a SARS-CoV-2 R.1 Lineage Variant in a Skilled Nursing Facility After Vaccination Program - Kentucky, March 2021. MMWR Morb Mortal Wkly Rep. 2021;70(17):639-643.

42. Mulligan MJ, Lyke KE, Kitchin N, et al. Phase I/II study of COVID-19 RNA vaccine BNT162b1 in adults. Nature. 2020;586(7830):589-593.

43. Lustig Y, Nemet I, Kliker L, et al. Neutralizing Response against Variants after SARS-CoV-2 Infection and One Dose of BNT162b2. N Engl J Med. 2021.

44. Chang X, Augusto GS, Liu X, et al. BNT162b2 mRNA COVID-19 vaccine induces antibodies of broader cross-reactivity than natural infection but recognition of mutant viruses is up to 10-fold reduced.Allergy. 2021.

Figure 1. Flow Diagram of the sample of residents from 22 nursing homes having faced a COVID-19 outbreak between March and December 2020.

Figure 2. Correlation between N- and S-protein IgG depending on the time of the COVID-19 infection 3 weeks after the first jab
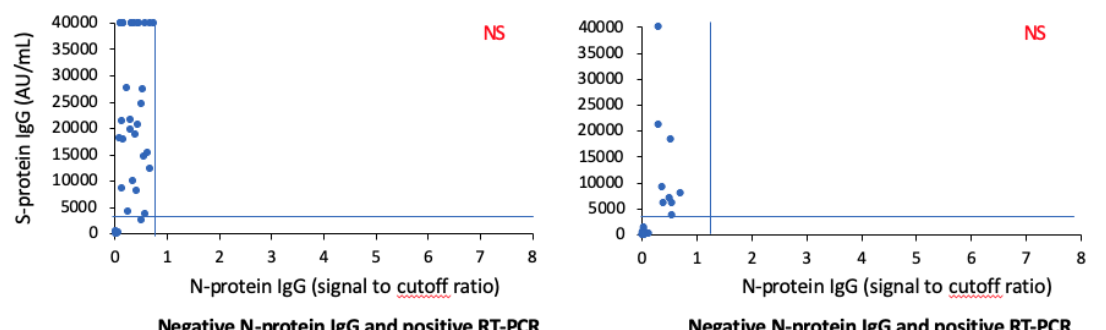

Negative $\mathrm{N}$-protein IgG and positive RT-PCR 9 to 12 months before vaccine $(n=35)$
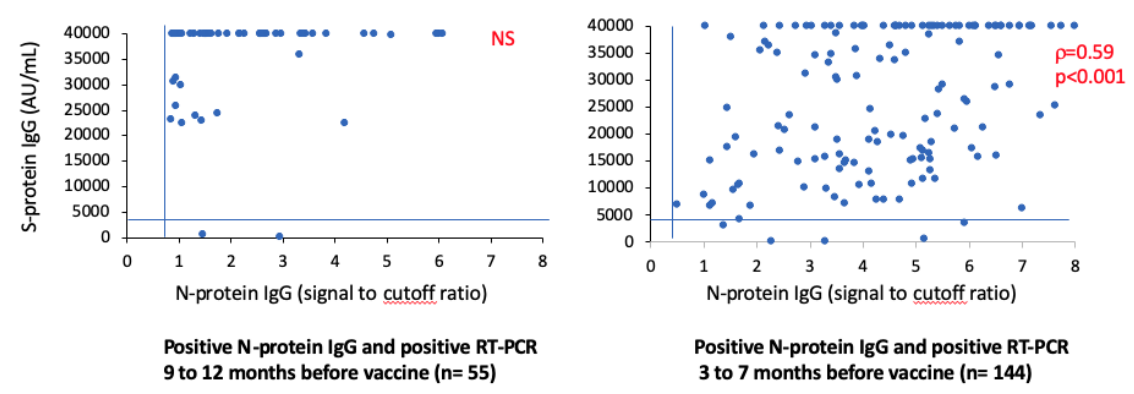

Legend: N-protein IgG levels: positive value when [?] 0.8 signal to cutoff ratio (vertical bars); S-protein IgG levels: high values when [?] 4160 arbitrary unit (AU)/mL (horizontal bar)

Figure 3: S-protein IgG levels in residents with or without prior COVID-19 3 weeks after the first jab and 6 weeks after the second 


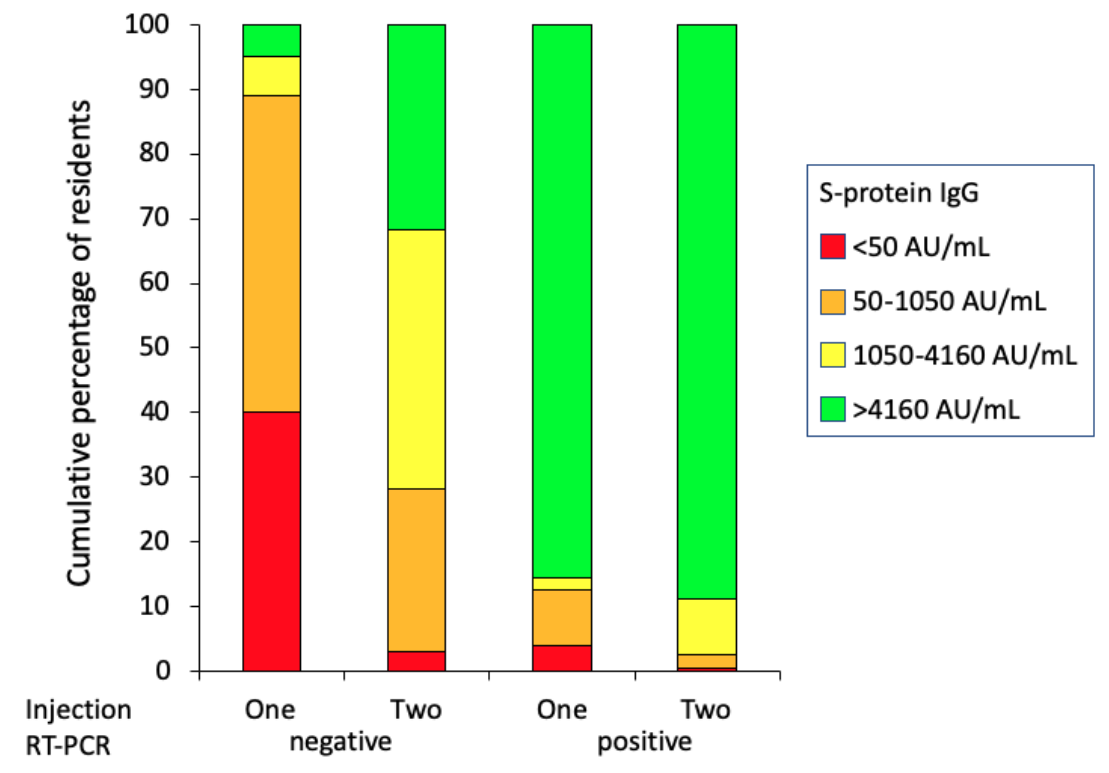

Table 1: Demographic characteristics and N-Protein IgG and S-Protein levels of the whole sample of nursing home residents 3 weeks after the first jab

\begin{tabular}{|c|c|c|c|c|c|c|c|}
\hline & $\begin{array}{l}\text { Repeated } \\
\text { negative } \\
\text { RT-PCR in } \\
\text { the last } 12 \\
\text { months } \\
(\mathrm{n}=735)\end{array}$ & $\begin{array}{l}\text { Repeated } \\
\text { negative } \\
\text { RT-PCR in } \\
\text { the last } 12 \\
\text { months } \\
(\mathrm{n}=735)\end{array}$ & $\begin{array}{l}\text { Positive } \\
\text { RT-PCR } \\
(n=270)\end{array}$ & $\begin{array}{l}\text { Positive } \\
\text { RT-PCR } \\
(\mathrm{n}=270)\end{array}$ & $\begin{array}{l}\text { Positive } \\
\text { RT-PCR } \\
(\mathrm{n}=270)\end{array}$ & $P$ value & \\
\hline & $\begin{array}{l}\text { Negative } \\
\text { N-Protein } \\
\operatorname{IgG}^{\mathrm{a}}(\mathrm{n}= \\
693)\end{array}$ & $\begin{array}{l}\text { Positive } \\
\text { N-Protein } \\
\text { IgG }^{\mathrm{b}} \\
(\mathrm{n}=42)\end{array}$ & $\begin{array}{l}\text { Positive } \\
\text { N-Protein } \\
\text { IgG }^{\mathrm{b}} \\
(\mathrm{n}=42)\end{array}$ & $\begin{array}{l}9 \text { to } 12 \\
\text { months } \\
\text { ago }^{\mathrm{c}} \\
(\mathrm{n}=94)\end{array}$ & $\begin{array}{l}3 \text { to } 7 \\
\text { months } \\
\text { ago }^{d} \\
(n=176)\end{array}$ & & \\
\hline $\begin{array}{l}\text { Sex Female } \\
(\%) \text { Male } \\
(\%)\end{array}$ & $\begin{array}{l}484(69.8) \\
209(30.2)\end{array}$ & $\begin{array}{l}35(83.3) 7 \\
(16.7)\end{array}$ & $\begin{array}{l}35(83.3) 7 \\
(16.7)\end{array}$ & $\begin{array}{l}66(70.2) 28 \\
(29.8)\end{array}$ & $\begin{array}{l}139(78.0) \\
37(21.0)\end{array}$ & .03 & .03 \\
\hline $\begin{array}{l}\text { Age, mean } \\
\text { (SD), year }\end{array}$ & $86.2(0.0)$ & $85.3(7.0)$ & $85.3(7.0)$ & $86.6(9.2)$ & $87.8(8.2)$ & .05 & .05 \\
\hline $\begin{array}{l}\text { SARS-CoV- } \\
2 \text { N-Protein } \\
\text { IgG level [?] } \\
0.8 \text { signal to } \\
\text { cutoff ratio, } \\
\text { No. }(\%)\end{array}$ & 0 & $42(100)$ & $42(100)$ & $55(61.1)$ & $144(83.7)$ & $\begin{array}{l}<.001 \\
\text { between }{ }^{c} \\
\text { and }{ }^{d}\end{array}$ & $\begin{array}{l}<.001 \\
\text { between }{ }^{c} \\
\text { and }{ }^{d}\end{array}$ \\
\hline $\begin{array}{l}\text { SARS-CoV- } \\
2 \text { N-Protein } \\
\text { IgG level, } \\
\text { median } \\
\text { (IQR) } \\
\text { [range], } \\
\text { AU/mL }\end{array}$ & 0 & $\begin{array}{l}3.4(0.8 ; 7.3) \\
{[0.8-7.3]}\end{array}$ & $\begin{array}{l}3.4(0.8 ; 7.3) \\
{[0.8-7.3]}\end{array}$ & $\begin{array}{l}1.0(0.4 ; 2.6) \\
{[0.02-6.1]}\end{array}$ & $\begin{array}{l}3.91 \\
(1.9 ; 5.3) \\
{[0.01-8]}\end{array}$ & $\begin{array}{l}<.001 \\
\text { between c } \\
\text { and }{ }^{b, d}\end{array}$ & $\begin{array}{l}<.001 \\
\text { between }{ }^{c} \\
\text { and }{ }^{b, d}\end{array}$ \\
\hline
\end{tabular}




\begin{tabular}{|c|c|c|c|c|c|c|c|}
\hline & $\begin{array}{l}\text { Repeated } \\
\text { negative } \\
\text { RT-PCR in } \\
\text { the last } 12 \\
\text { months } \\
(\mathrm{n}=735)\end{array}$ & $\begin{array}{l}\text { Repeated } \\
\text { negative } \\
\text { RT-PCR in } \\
\text { the last } 12 \\
\text { months } \\
(\mathrm{n}=735)\end{array}$ & $\begin{array}{l}\text { Positive } \\
\text { RT-PCR } \\
(\mathrm{n}=270)\end{array}$ & $\begin{array}{l}\text { Positive } \\
\text { RT-PCR } \\
(\mathrm{n}=270)\end{array}$ & $\begin{array}{l}\text { Positive } \\
\text { RT-PCR } \\
(\mathrm{n}=270)\end{array}$ & $P$ value & \\
\hline $\begin{array}{l}\text { SARS- } \\
\text { CoV-2 } \\
\text { S-protein } \\
\text { IgG level }\end{array}$ & & & & & & & \\
\hline $\begin{array}{l}0-50 \\
\mathrm{AU} / \mathrm{mL}\end{array}$ & $288(41.7)$ & $5(11.9)$ & $5(11.9)$ & $8(4.6)$ & $2(2.1)$ & & \\
\hline $\begin{array}{l}50-1050 \\
\mathrm{AU} / \mathrm{mL}\end{array}$ & $343(49.6)$ & $5(11.9)$ & $5(11.9)$ & $15(8.6)$ & $6(6.4)$ & & \\
\hline $\begin{array}{l}1050-4160 \\
\mathrm{AU} / \mathrm{mL}\end{array}$ & $47(6.8)$ & $1(2.4)$ & $1(2.4)$ & $5(2.8)$ & $3(3.2)$ & & \\
\hline $\begin{array}{l}{[?] \quad 4160} \\
\mathrm{AU} / \mathrm{mL}\end{array}$ & $13(1.9)$ & $31(73.8)$ & $31(73.8)$ & $147(84.0)$ & $83(88.3)$ & & \\
\hline $\begin{array}{l}\text { SARS-CoV- } \\
2 \text { S-protein } \\
\text { level median } \\
\text { (Q1-Q3) } \\
\text { [range], } \\
\text { AU/mL }\end{array}$ & $\begin{array}{l}82 \\
(16-296)[0- \\
40,000]\end{array}$ & $\begin{array}{l}21,736 \\
(16,229) \\
{[0-40,000]}\end{array}$ & $\begin{array}{l}21,736 \\
(16,229) \\
{[0-40,000]}\end{array}$ & $\begin{array}{l}40,000 \\
(9,146- \\
40,000) \\
{[6-14142]}\end{array}$ & $\begin{array}{l}20,796 \\
(4157 ; 40000) \\
{[1-40,000]}\end{array}$ & $\begin{array}{l}<.001 \\
\text { between }^{a} \\
\text { and }^{\mathrm{b}, \mathrm{c}, \mathrm{d}} \\
<.001 \\
\text { between }^{\mathrm{c}} \\
\text { and }^{\mathrm{b}, \mathrm{d}}\end{array}$ & $\begin{array}{l}<.001 \\
\text { between }^{\text {a }} \\
\text { and }^{\mathrm{b}, \mathrm{c}, \mathrm{d}} \\
<.001 \\
\text { between }^{\mathrm{c}} \\
\text { and }^{\mathrm{b}, \mathrm{d}}\end{array}$ \\
\hline
\end{tabular}

Table 2: S-Protein IgG levels in RT-PCR-positive residents 3 weeks after the first jab

\begin{tabular}{|c|c|c|c|c|c|}
\hline & $\begin{array}{l}\text { Negative } \\
\text { N-Protein IgG } \\
\text { in the last } 9 \text { to } \\
12 \text { months }^{\mathrm{a}}\end{array}$ & $\begin{array}{l}\text { Positive } \\
\text { N-Protein IgG } \\
\text { in the last } 9 \text { to } \\
12 \text { months }^{b}\end{array}$ & $\begin{array}{l}\text { Negative } \\
\text { N-Protein IgG } \\
\text { in the last } 3 \text { to } \\
7 \text { months }^{\mathrm{c}}\end{array}$ & $\begin{array}{l}\text { Positive } \\
\text { N-Protein IgG } \\
\text { in the last } 3 \text { to } \\
7 \text { months }^{\mathrm{d}}\end{array}$ & $P$ value \\
\hline & 39 & 55 & 32 & 144 & \\
\hline $\begin{array}{l}\text { IgG level [?] } \\
50 \mathrm{AU} / \mathrm{ml} \text { No. } \\
(\%)\end{array}$ & $34(97.1)$ & $55(100.0)$ & $21(75.0)$ & $144(100.0)$ & $\begin{array}{l}\mathrm{p}<0.001 \\
\text { between }{ }^{\mathrm{c}} \text { and } \\
\mathrm{a}, \mathrm{b}, \mathrm{d}\end{array}$ \\
\hline $\begin{array}{l}\text { median level } \\
\text { [range], } \mathrm{AU} / \mathrm{ml}\end{array}$ & $\begin{array}{l}20,685 \\
{[13,-40,000]}\end{array}$ & $\begin{array}{l}40,000[67- \\
40,000]\end{array}$ & $230[1-40,000]$ & $\begin{array}{l}27313 \\
{[210-40,000]}\end{array}$ & $\begin{array}{l}\mathrm{p}<0.001 \text { between } \\
\mathrm{c} \text { and }{ }^{\mathrm{a}, \mathrm{b}, \mathrm{d}}\end{array}$ \\
\hline
\end{tabular}

Abbrevations: AU, arbitrary units; IQR, interquartile range

\begin{tabular}{lllll}
\hline $\begin{array}{l}\text { Repeated } \\
\text { negative }\end{array}$ & $\begin{array}{l}\text { Repeated } \\
\text { negative }\end{array}$ & & \\
RT-PCR in the & RT-PCR in the & Positive & Positive & \\
last 12 months & $\begin{array}{l}\text { last 12 months } \\
(\mathrm{n}=589)\end{array}$ & $\begin{array}{l}\text { RT-PCR } \\
(\mathrm{n}=222)\end{array}$ & $\begin{array}{l}\text { RT-PCR } \\
(\mathrm{n}=222)\end{array}$ & $P$ value \\
\hline Negative & Positive & 9 to 12 months & 3 to 7 months & \\
N-Protein & N-Protein & $\operatorname{ago}^{\mathrm{c}}(\mathrm{n}=72)$ & $\operatorname{ago}^{\mathrm{d}}(\mathrm{n}=150)$ & \\
$\operatorname{IgG}^{\mathrm{a}}(\mathrm{n}=554)$ & $\operatorname{IgG}^{\mathrm{b}}(\mathrm{n}=35)$ & & &
\end{tabular}




\begin{tabular}{|c|c|c|c|c|c|}
\hline & $\begin{array}{l}\text { Repeated } \\
\text { negative } \\
\text { RT-PCR in the } \\
\text { last } 12 \text { months } \\
(\mathrm{n}=589)\end{array}$ & $\begin{array}{l}\text { Repeated } \\
\text { negative } \\
\text { RT-PCR in the } \\
\text { last } 12 \text { months } \\
(\mathrm{n}=589)\end{array}$ & $\begin{array}{l}\text { Positive } \\
\text { RT-PCR } \\
(\mathrm{n}=222)\end{array}$ & $\begin{array}{l}\text { Positive } \\
\text { RT-PCR } \\
(\mathrm{n}=222)\end{array}$ & $P$ value \\
\hline $\begin{array}{l}\text { Sex Female }(\%) \\
\text { Male }(\%)\end{array}$ & $\begin{array}{l}387(69.9) 167 \\
(30.1)\end{array}$ & $32(91.4) 3(8.6)$ & $\begin{array}{l}52(72.2) 20 \\
(27.8)\end{array}$ & $\begin{array}{l}121(80.7) 29 \\
(19.3)\end{array}$ & $<.01$ \\
\hline $\begin{array}{l}\text { Age, mean } \\
\text { (SD), year } \\
\text { SARS-CoV-2 } \\
\text { S-protein IgG } \\
\text { level }\end{array}$ & $86.2(9.0)$ & $85.6(7.2))$ & $87.4(8.6)$ & $88.0(8.5)$ & NS \\
\hline $0-50 \mathrm{AU} / \mathrm{mL}$ & $17(3.1)$ & $1(2.9)$ & $0(0)$ & $1(0.7)$ & \\
\hline $\begin{array}{l}50-1050 \\
\mathrm{AU} / \mathrm{mL}\end{array}$ & $146(26.3)$ & $2(5.7)$ & $0(0)$ & $5(3.3)$ & \\
\hline $\begin{array}{l}1050-4160 \\
\mathrm{AU} / \mathrm{mL}\end{array}$ & $231(41.7)$ & $5(14.3)$ & $6(8.3)$ & $12(8.0)$ & \\
\hline $\begin{array}{l}{[?] 4160} \\
\mathrm{AU} / \mathrm{mL}\end{array}$ & $160(28.9)$ & $27(77.1)$ & $66(91.7)$ & $132(88.0)$ & \\
\hline $\begin{array}{l}\text { SARS-CoV-2 } \\
\text { S-protein level } \\
\text { median (Q1-Q3) } \\
\text { [range], AU/mL }\end{array}$ & $\begin{array}{l}2384(827 ; \\
4902)[0-40,000]\end{array}$ & $\begin{array}{l}18239(5876 \\
38418)[0 \\
40000][0-40,000]\end{array}$ & $\begin{array}{l}39525(19601 ; \\
4000)[6-14142]\end{array}$ & $\begin{array}{l}28863(12083 ; \\
40000)[1-40,000]\end{array}$ & $\begin{array}{l}<.001 \text { between }^{\mathrm{a}} \\
\text { and }{ }^{\mathrm{b}, \mathrm{c}, \mathrm{d}}<.001 \\
\text { between }{ }^{\mathrm{c}} \text { and } \\
\mathrm{b}, \mathrm{d}\end{array}$ \\
\hline
\end{tabular}

Table 3: Demographic characteristics and N-Protein IgG and S-Protein levels of the whole sample of nursing home residents after the second jab 